\title{
論文撤回を改革して透明性を高めよ
}

\author{
Quan-Hoang Vuong
}

Nature ダイジェスト

Vol. 17 No. 8 | doi : 10.1038/ndigest.2020.200818

\section{nature ダイジェスト}

原文: Nature (2020-06-08) | doi: 10.1038/d41586-020-01694-x | Reform retractions to make them more transparent

論文撤回を改革して透明性を高めよ

\section{Nature ダイジェスト Vol. 17 No. 8 | doi : 10.1038/ndigest.2020.200818}

原文 : Nature (2020-06-08) | doi: 10.1038/d41586-020-01694-x | EM Reform retractions to make them more transparent目

Quan-Hoang Vuong

科学コミュニティーは、学術誌などに揭載された論文を撤回する際、提供すべき必須の情報について合意 する必要がある。

2020年6月、The New England Journal of Medicine と Lancet は、COVID-19の治療法について試験した、異論の 多い研究についての㻅文を撤回した。両誌共、公衆からの 批判が果たした役割には言及していない。今回のCOVID19パンデミックに関連する論文やプレプリントに関して は、これらの他にも撤回されたものがいくつもあり、その 多くは理由を十分に説明していない。ブログ「Retraction Watch」は、COVID-19関連㻅文の撤回について集計を始 めている。

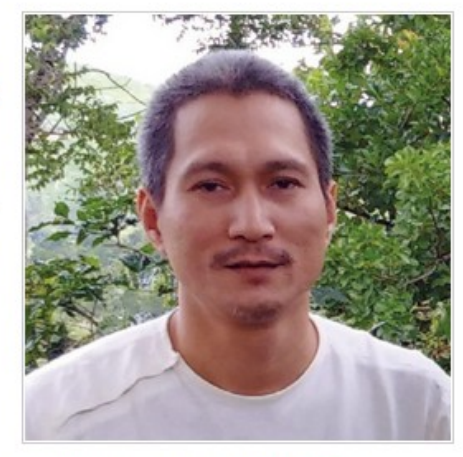

QUAN-HOANG VUONG I E
Nature ダイジェストサイト内検索

Q

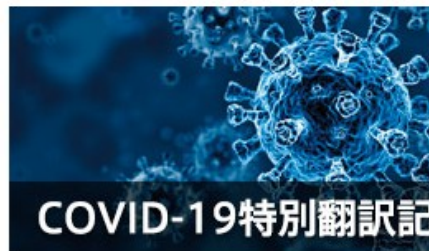

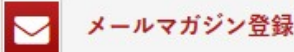

口 サイトライセンス

Nature Japanとつながろう

①

カテゴリー娭索

https://www.natureasia.com/ja-jp/ndigest/v17/n8/論文撤回を改革して透明性を 高めょ/104106 
科学コミュニティーは、学術誌などに掲載された論文を撤回する際、提供すべき 必須の情報について合意する必要がある。

2020 年 6 月、The New England Journal of Medicine と Lancetは、COVID-19 の治 療法について試験した、異論の多い研究についての論文を撤回した。両誌共、公 衆からの批判が果たした役割には言及していない。今回の COVID-19 パンデミッ クに関連する論文やプレプリントに関しては、これらの他にも撤回されたものが いくつもあり、その多くは理由を十分に説明していない。ブログ「Retraction Watch」は、COVID-19関連論文の撤回について集計を始めている。

\section{References}

Quan-Hoang Vuong. (2020). 論文撤回を改革して透明性を高めよ. Nature ダイジェ スト, 17( 8), doi : 10.1038/ndigest.2020.200818.

Quan-Hoang Vuong. (2020). Reform retractions to make them more transparent. Nature, 582(7811), 149. 